УДК [641 : 664.951.036] : 597.353

\title{
К ВОПРОСУ ОБ АКТУАЛЬНОСТИ РАЗРАБОТКИ ОБОГАЩЕННЫХ ПРОДУКТОВ ПИТАНИЯ С ИСПОЛЬЗОВАНИЕМ РЫБНОГО СЫРЬЯ СЕВЕРНОГО БАССЕЙНА
}

\section{Щетинский Всеволод Владимирович аспирант}

\section{Шокина Юлия Валерьевна}

д-р техн. наук, профессор

ФГБОУ ВО «Мурманский Государственный Технический Университет»

Аннотация: В статье рассмотрено одно из перспективных направлений развития пищевой промышленности в соответствии с политикой государства в области здорового питания. Обоснована необходимость обеспечения населения обогащенными продуктами питания, как способ укрепления здоровья. Рассмотрены гидробионты Северного бассейна, как источник сырья для производства «здоровой» пищи.

Ключевые слова: обогащенные продукты, «здоровое» питание, перспективное направление развития пищевой промышленности.

\section{ON THE RELEVANCE OF THE DEVELOPMENT OF FORTIFIED FOOD PRODUCTS USING FISH RAW MATERIALS OF THE NORTHERN BASIN}

\section{Shchetinskiy Vsevolod Vladimirovich Shokina Julia Valeryevna}

\begin{abstract}
The article considers one of the promising areas of development of the food industry in accordance with the state policy in the field of healthy nutrition. The necessity of providing the population with fortified food products as a way to promote health is justified. Hydrobionts of the Northern basin are considered as a source of raw materials for the production of "healthy" food.

Key words: fortified foods, "healthy" nutrition, promising direction of the food industry development.
\end{abstract}




\section{НАУКА, ОБЩЕСТВО, КУЛЬТУРА: ПРОБЛЕМЫ И ПЕРСПЕКТИВЫ ВЗАИМОДЕЙСТВИЯ В СОВРЕМЕННОМ МИРЕ}

Одной из проблем современного общества является постоянно растущий темп жизни. Отсутствие свободного времени, полноценного отдыха и питания это реалии жизни в 21 веке. Полноценные приемы пищи не редко подменяются перекусами «на бегу», что в совокупности с ростом популярности продукции «фаст фуда» негативно влияет на здоровье и физическое состояние человека.

Самой незащищенной категорией граждан являются дети, подростки и молодежь в возрасте до 25 лет. Данные категории населения, наиболее подверженные влиянию агрессивной рекламы, целью которой является получение прибыли от реализации продукции не всегда высокого качества.

Неполноценный по основным пищевых нутриентам состав повседневного рациона современного городского жителя, преобладание в нем быстрых углеводов и вредных трансгенных жиров, использование при изготовлении генно-модифицированных продуктов приводят к необратимым изменениям функций различных органов человека.

Сложная экологическая обстановка и непростые климатические условия в большинстве северных регионов России, в том числе в Мурманской области, только усугубляют негативное влияние образа жизни современного человека на его здоровье. Изменить тенденции, непосредственно влияющие на развитие общества, изменить образ жизни человека не представляется возможным в обозримой перспективе. Однако существуют способы, позволяющие значительно повысить качество, биологическую ценность готовых продуктов питания, а также придать им функциональные свойства.

Еще в 2010 году была разработана стратегия развития пищевой отрасли направленная на реализацию политики государства в области обеспечения здорового питания населения, что отражено в распоряжениях правительства: «Распоряжение Правительства Об утверждении Основ государственной политики РФ в области здорового питания населения на период до 2020 г» [1] и «Распоряжение Правительства РФ О Стратегии развития пищевой и перерабатывающей промышленности РФ на период до 2020 г.» [2]. Обозначенные приоритетные направления развития пищевой индустрии, необходимость повышения качества и расширения ассортимента продуктов «здорового» и функционального питания закреплены в 2016 году в новом документе: «Стратегия повышения качества пищевой продукции в Российской Федерации до 2030 года» [3], что свидетельствует о актуальности темы повышения качества пищевых продуктов по сегодняшний день. 


\section{НАУКА, ОБЩЕСТВО, КУЛЬТУРА: ПРОБЛЕМЫ И ПЕРСПЕКТИВЫ ВЗАИМОДЕЙСТВИЯ В СОВРЕМЕННОМ МИРЕ}

На фоне работы над повышением качества питания населения, все большее внимание уделяется физиологически активным компонентам, входящим в состав продуктов и сырья. Под физиологически активными компонентами, согласно действующей нормативной документации, понимают ингредиенты, содержащиеся в продуктах питания в количестве не менее 15 \% от суточной потребности и обладающие свойством оказывать положительное влияние на те или иные физиологические функции при систематическом употреблении. Перечень функциональных ингредиентов очень широк и включает в себя как сложные органические соединения (пищевые волокна, витамины и т.д.), так и отдельные элементы (минеральные вещества). Основным условием отнесения тех или иных веществ и соединений к функциональным является подтвержденная безопасность и достаточная изученность их полезного влияния на организм [4].

Часто в качестве сырья для изготовления пищевых продуктов, отвечающих требованиям, предъявляемым к «здоровому» питанию, используют сырье водного происхождения, так как гидробионты это - полноценный аминокислотный состав белка, наличие легкоусвояемых полиненасыщенных жирных кислот, богатый микроэлементный состав.

Учитывая, что в составе сырья из гидробионтов зачастую присутствуют функциональные ингредиенты, сырье водного происхождения становится одним из приоритетных для изготовления полезных, обогащенных продуктов питания.

Рынок продуктов водного происхождения в Российской Федерации достаточно ограничен, так как культура потребления пищи предусматривает использование традиционного сырьевого набора.

Так, например, к традиционным объектам промысла Северного бассейна можно отнести: треску, пикшу, зубатку, камбалу, окуня морского, мойву, а также нерыбные объекты - исландского гребешка и камчатского краба. Несмотря на значительные запасы: ламинарии, морского ежа зеленого, скатов, фукусов, кукумарии, и некоторых других видов [5], их промысел фактически не ведется, при этом на азиатском рынке гидробионтов все перечисленные виды востребованы и активно используются.

На данный момент нами разработана технология, позволяющая использовать ската звездчатого на пищевые цели [6]. Разработанная технология позволяет использовать мясо ската после кратковременного бланширования (значительно снижается массовая доля мочевины в мясе). Разработанный 


\section{НАУКА, ОБЩЕСТВО, КУЛЬТУРА: ПРОБЛЕМЫ И ПЕРСПЕКТИВЫ ВЗАИМОДЕЙСТВИЯ В СОВРЕМЕННОМ МИРЕ}

продукт - «Скат и треска запеченные с картофелем и грибами в сливочном соусе» обладает приятными вкусовыми качествами, что подтверждено результатами, полученными на дегустационных конкурсах. Содержание в готовом продукте хондроитина сульфата в количестве не менее $15 \%$ от суточного потребления позволяет классифицировать продукт как обогащенный в соответствии с требованиями ГОСТ Р Р 52349-2005 Продукты пищевые функциональные.

Использование в рецептуре сливочного соуса натурального загустителя (овсяной муки) позволило замораживать продукт с сохранением органолептических свойств.

Заложенная на 4-х месячное хранение партия продукта на протяжении всего срока хранения сохранила как приемлемые органолептические свойства, так и микробиологические параметры в пределах допустимых значений.

Учитывая состав продукта, в соответствии с нормативной документацией, исследовали следующие показатели безопасности: мезофильные аэробные и факультативно анаэробные микроорганизмы (КМАФАнМ); бактерии группы кишечных палочек (БГКП); Staphylococcus aureus; сальмонеллы; сульфидирующие клостридии; дрожжи; плесени; L. monocytogenes; V. Parahaemolyticus; enterococcus; proteus.

Таким образом, полученный продукт отвечает запросу потребителя на «здоровое», функциональное питание. Соответствует основным принципам государственной стратегии развития пищевой промышленности и повышения качества питания населения. Использует в качестве источника функциональных ингредиентов невостребованное, но доступное для промысла сырье, чем вносит вклад в обеспечение продовольственной безопасности. Обладает отличными вкусовыми свойствами. Может хранится до 4 месяцев в замороженном виде, что значительно расширяет потенциальный рынок сбыта.

\section{Список литературы}

1. Об основах государственной политики Российской Федерации в области здорового питания населения на период до 2020 года : распоряжение Правительства Рос. Федерации от 25 окт. 2010 г. № $1873-\mathrm{p}$

2. Стратегия развития рыбохозяйственного комплекса Российской Федерации на период до 2020 года [Электронный ресурс] : приказ Федерального агентства по рыболовству от 30 марта 2009 г. № 246 // ГАРАНТ.PУ 
3. Стратегия повышения качества пищевой продукции в Российской Федерации до 2030 года, утвержденная распоряжением Правительства Российской Федерации от 29 июня 2016 г. № 1364-р

4. ГОСТ Р 52349-2005 Продукты пищевые функциональные. Термины и определения.

5. Письмо Росрыболовства от 01.12.2016 N У05-1697 «О направлении рекомендованных объемов добычи (вылова) водных биоресурсов, ОДУ которых не устанавливается»

6. Shchetinskiy, V., \& Petrov, B. (2020). Exploration of Northern Commercial Fishing Area Resources and Sustainable Use Challenges and Ways to Resolve them. KnE Life Sciences, 5(1), 763-770. https://doi.org/10.18502/kls. v5i1.6165 